\title{
The Implementation of Training Model to Improve Professional Competence of Teachers in Inclusive Education
}

\author{
Irdamurni \\ Department of Special Need Education \\ Universitas Negeri Padang, Indonesia \\ irdamurni@fip.unp.ac.id
}

\section{Zulmiyetri}

Department of Special Need Education

Universitas Negeri Padang, Indonesia zulmiyetri@fip.unp.ac.id

\author{
Nurhastuti \\ Department of Special Need Education \\ Universitas Negeri Padang, Indonesia \\ nurhastuti@fip.unp.ac.id
}

\author{
Megaiswari \\ Department of Special Need Education \\ Universitas Negeri Padang, Indonesia \\ Mega_iswari@fip.unp.ac.id
}

\begin{abstract}
The problems that occurred in Padang Elementary School that most teachers do not have competence in inclusive education. Have not found the model is effective and practical training to improve the competence of teachers in the implementation of inclusive education, this study aims to build a model of training to improve the competence of teachers in implementing inclusive education in primary schools, as well as test the effectiveness and practicalities of training models to improve the competence of teachers in inclusive education. The findings of the study indicate: (a) there is a significant increase on the professional competence of teachers on Inclusive Education implemented the model after training, with an average value are given training before $67.5 \%$, which is in enough categories, whereas after training given rise to higher categories $80.6 \%$. (b) the training model is considered practical, valid and effective for implementing the Inclusive Education training program for elementary school teachers, it is seen the result analysis of participants' responses on average, $82 \%$ stated that training model developed states very practical, effective and fun, and not boring.
\end{abstract}

Keywords: training model, inclusive education, teacher, professional competency

\section{INTRODUCTION}

Arrangement of inclusive education has been implemented in Padang since the year 2005, and the government has sparked the lastest Inclusive education Act, Ministerial Decree No 70 the year 2009 about inclusive education for learners who have special needs and gifted and talented. Inclusive education allows everyone to obtain an education, including students with special needs, as outlined in the Law No. 20 the year 2003 about National Education System, Article 1 Section 4, states that every citizen has an equal right to obtain a quality education, including children with special needs.

Shevin (2007) believes inclusive education as an education service system requires that all children with special needs are served in schools nearby, in regular classes together friends of his age. Therefore, emphasized the restructuring of the school, so that it becomes a community that supports the fulfillment of the special needs of each child. It means the school has adequate learning resources and the support of all members of the school, such as students, teachers, parents, and surrounding community. Through inclusive education, children with special needs are educated together with other children (normal) to optimize its potential (Skjørten, Miriam D. 2001). It is based on the fact that in society, children with and without special needs can not be separated as a community.

In the implementation of inclusive education, it has not been implemented as expected. Earlier research indicates that competence of primary school teachers about inclusive education in Padang is low (Irdamurni, 2018). This causes the implementation of inclusive education is not operated according to the established criteria. Author interviews with primary school teachers who have been organizing inclusive education, they said that most of them have not received training on the implementation of inclusive education, so they implemented about inclusive education in according to the concept that they understand. Moreover, the book of instructions on the arrangement of inclusive education has not been widely sold

The low competence of teachers in understanding the concept of inclusive education needs to be improved so that teachers get the appropriate concept of inclusive education. Competencies should be admitted by educators because with a good competency, teachers will be able to develop learners to achieve educational goals. Competence is a set of knowledge and skills that should be admitted by a person to accomplish their duties. 
Knowledge and skills can be obtained in the preemployment training and/or training.

According to the results, it has developed a valid, practical and effective training model for inclusive education to improve the pedagogical and professional competence of teachers in implementing inclusive education in primary schools. The training model that the authors have developed consists of three books, namely the book 1 about the technical arrangement of inclusive education training, book 2 contains about the program and plans of inclusive education training, and book 3 about module of the training, as a material guide to the instructor about the material that required by the teacher in a working session on inclusive education. Based on the description, the results of the training model of inclusive education that has been developed and then trained to teachers, so that it can improve the professional competence of teachers in the understanding of inclusive education.

\section{METHOD}

This study use research and development approach. According to Borg \& Gall (2003) research and development is a process used to develop and validate educational products. Development procedures used follow the step-by-step methods of research and development proposed by Sugiyono (2011), which consists of 10 steps. While the technique of data analysis using descriptive statistics and inferential.

The sample of this study is primary school teachers who have taught in inclusive classrooms for at least two years, and special teachers who teach in inclusive classrooms. The total sample is 30 teachers from 12 primary inclusive schools in Padang, which consists of 15 regular teacher in primary schools and 15 special teachers in inclusive school. Purposive sampling technique is used in this study

The training model was formulated based on the study of problems that occur in the field, especially according to the competence of teachers about the implementation of inclusive education in primary schools. Then the researcher designed a training model with the goal of model training can improve the competence of teachers in implementing inclusive education in primary schools. The competency restricted at professional competence. The model has been tested in order to determine the validity, practicality, and effectiveness of the model.

Training model developed refers to the opinion of Trianto, 2009 that the steps used in the development of the training program are as follows: (1) need assessment, (2) training and development objective, (3) program content, (4) learning principles, (5) actual program, (6) skill knowledge ability of work, and (7) evaluation.

\section{RESULT}

Operationally, the training model is proven to improve the professional competence of teachers in implementing inclusive education, it is evidenced by the pre and posttest score of training participants. There is an increase in the mean score. Before training, the mean score of training participants is $57.8 \%$, which is in the category of less, whereas after being given the training increased to $76.7 \%$ that is in the good category. The next proof can also be seen from the results of the instruments the questionnaire of training participants about professional competence. Before the training, training participants' score was $67.5 \%$, which is in the category of fairly, but after training, participants' score increased to $80.6 \%$, which is in the high category. It means that there is a significant increase in the professional competence of primary school teachers after training about inclusive education. I also mean the training model of inclusive education can enhance the professional competence of primary school teachers.

The analysis results about participants' response to the training show $90.8 \%$ of training participants stated that the training model applied is captivated by the participants. $87.5 \%$ stated that the training model is exciting and interesting. Substantially, $85.8 \%$ of the participants stated that the training methods help the teacher in understanding the training material. $80.8 \%$ of training participants stated that the training materials help teachers in increasing competence of organizing inclusive education. $92.53 \%$ of training participants stated the material provided according to the problems and needs of teachers. $79.1 \%$ of training participants stated that the examples suitable to the problem in the field. $75 \%$ of training participants stated that the time provided in the training enough to improve the competence of teachers in implementing inclusive education in schools.

\section{DISCUSSION}

Based on the result, it showed that the model is valid and can be used in order to improve the competence of primary school teachers in implementing inclusive education. Similarly, the practicality of the training model, the results of the observation, the interview results and questionnaire results from the raining participants showed that the training conducted is not boring, raises the motivation and enthusiasm of participants. The varies method tailored to an adult such as using lectures, question, and answer, reflection, discussion, watching a movie, giving the task action plant, etc make this model interesting to the participants. This is according to the opinion of the Suprijanto (2008) that need to be considered in adult education including; the presentation of formal, i.e. lectures, question and answer, discussion, symposium, audiovisual (watching a movie) and others.

The opinion was also supported by Lunandi (1982) and Soedomo (1989) said that a conducive learning atmosphere for adults is as follows: (1) encourage learners to be active and develop their talent, (2) an atmosphere of mutual respect, (3) an atmosphere of mutual trust and open-minded, (4) atmosphere self-inquiry, (5) the atmosphere is not threatening, (6) the atmosphere of the admitted peculiarities of the person, (7) the atmosphere to allow for difference, mistakes, and indecision, (8) allows learners to learn according to their interests, (9) allows learners to recognize and assess the strengths and weaknesses of personal, group, and society, (10) allowing learners to grow in according to the values and norms that exist in society. The requirements above applied in the model training using a training method that has been 
developed such as requesting a reflection of the participants after the material presented, providing reinforcement to participants who actively provide opinions and input as well as questions in learning. Other opinions are also presented Trianto (2009) that a model is effective if meets the following requirements; (1) experts and practitioners based on her experience stating the model is effective, and (2) operationally, such models give results as expected.

In order to determine the response of experts and practitioners, researchers have already conducted the validation to the expert. The judgments are the expert in management training, experts in inclusive education and experts in primary school. In order to determine the response of the practitioner, the researcher also held a Focus group Discussion (FGD) with several practitioners, including lecturers of special education department, regular teachers and special teacher, staff training of Education Department West Sumatera, the staff of LPMP West Sumatera and postgraduate students Universitas Negeri Padang. All the advice and input of the FGD participants are already concluded and used in revision the models.

\section{CONCLUSION}

The findings of the study indicate: (a) there is a significant increase on the professional competence of teachers on Inclusive Education implemented the model after training, with an average value are given training before $67.5 \%$, which is in enough categories, whereas after training given rise to higher categories $80.6 \%$. (b) the training model is considered practical, valid and effective for implementing the Inclusive Education training program for elementary school teachers, it is seen the result analysis of participants' responses on average, $82 \%$ stated that training model developed states very practical, effective and fun, and not boring.

\section{REFERENCES}

[1] Borg, W. R, \& Gall, M. D. 2003. Educational Reseach: An Introduction. London: Longman, Inc.

[2] Dick, W., \& Carey, L.1996. The systematic Design of instruction. (4 th.ed). New York: Harper Collinc College Publisher.

[3] Irdamurni. 2018. Memahami Anak Berekebutuhan Khusus. Bandung: Goresan Pena.

[4] Johnsen, Berit H dan Miriam D. Skjorten. 2003. Pendidikan Kebutuhan Khusus; Sebuah Pengantar, Bandung.

[5] UnipubLunandi. 1982. Pendidikan Orang dewasa sebuah uraian Praktis untuk Pembimbing, Penatar, Pelatih dan Penyuluh Lapangan. Jakarta: Asokadinata.

[6] Margo, A. Mastropieri, 2007. The Inclusive Classroom: Strategies for Effective Instruction. Pearson Education. Inc. Upper Saddle River, New Jersey. Colombus, Ohio.

[7] O’Neil, J. 1995 Can Inclusive Work ? A Conversation With James Kauffman and Mara Sapon-Sevin. Educational Leadership. 52(4)7-11.

[8] Permendiknas RI Nomor 70 tahun 2009 tentang Pendidikan Inklusif Bagi Peserta didik yang Memiliki Kelainan dan Memiliki Potensi Kecerdasan dan/atau Bakat Istimewa

[9] Shevin, S. 2007. Widening the Circle. The Power of Inclusive Classrooms. Boston: Beacon Press.

[10] Soedomo, M. 1989. Andragogi: Relevansi Teoritik dan Terapan. Jurnal Forum Penelitian Kependidikan, 1(1).

[11] Sugiyono. 2011. Metode Penelitian Pendidikan. Pendekatan. Kuantitatif, Kualitatif, dan $R \& D$. Bandung: Alfabeta.

[12] Suprijanto. 2008. Pendidikan Orang Dewasa. Jakarta: Bumi Aksara.

[13] Skjørten, Miriam D. 2001. Toward Inclusion and Enrichment. Article in Johnsen, Berit H. \& Skjørten, Miriam D. (ed). Educational - Special Needs Education: An Introduction. Oslo,

[14] Stainback, William. \& Stainback, Susan. 1990. Support Networks for Inclusive Schooling: Independent Integrated Education. Baltimore: Paul H. Brooks.

[15] Unipub.Trianto. 2009. Mendesain ModelPembelajaran Inovatif Pregresive. Jakarta: Kencana.. 